\title{
STRATEGI PERTUMBUHAN DAN PEMBANGUNAN EKONOMI DAERAH
}

\author{
Hanly Fendy Djohar Siwu \\ Staf Pengajar Pada Fakultas Ekonomi dan Bisnis \\ Universitas Sam Ratulangi Manado
}

\begin{abstract}
ABSTRAK
Kajian ini bertujuan untuk mengetahui strategi pertumbuhan dan pembangunan ekonomi daerah dalam rangka meningkatkan kapasitas pembangunan ekonomi yang ada disetiap daerah. Secara teoritis ada 3 strategi petumbuhan dan pembangunan ekonomi yakni: strategi upaya minimum kritis, strategi pembangunan seimbang dan strategi pembangunan tak seimbang. Sedangkan strategi pembangunan ekonomi daerah terdapat 4 strategi yakni: strategi pengembangan fisik/lokalitas, strategi pengembangan dunia usaha, strategi pengembangan sumberdaya manusia dan strategi pengembangan ekonomi masyarakat.
\end{abstract}

Kata kunci: Strategi pertumbuhan, pembangunan ekonomi, pembangunan ekonomi daerah.

\begin{abstract}
This study aims to determine the growth strategy and regional economic development in order to improve the capacity of economic development in each region. Theoretically there are three strategies of growth and economic development namely: critical minimum effort strategy, balanced development strategy and unbalanced development strategy. While the strategy of local economic development there are 4 strategies namely: physical / locality development strategy, business development strategy, human resource development strategy and community economic development strategy.
\end{abstract}

Keywords: growth strategy, economic development, regional economic development. 


\section{PENDAHULUAN}

Pengertian daerah berbeda-beda tergantung pada aspek tinjauannya. Dari aspek ekonomi,daerah mempunyai tiga pengertian yaitu:

1. Suatu daerah dianggap sebagai ruang di mana kegiatan ekonomi terjadi dan di dalam berbagai pelosok ruang tersebut terdapat sifat-sifat yang sama. Kesamaan sifat-sifat tersebut antara lain dari segi pendapatan per kapitanya, sosial budayanya, geografisnya, dan sebagainya. Daerah dalam pengertian seperti ini disebut daerah homogen.

2. suatu daerah dianggap sebagai suatu ekonomi ruang yang dikuasai oleh satu atau beberapa pusat kegiatan ekonomi.daerah dalam pengertian ini disebut daerah nodal.

3. suatu daerah adalah suatu ekonomi ruang yang berada di bawah satu administrasi tertentu seperti satu provinsi, kabupaten, kecamatan, dan sebagainya.Daerah dalam pengertian seperti ini dinamakan daerah perencanaan atau daerah administrasi.

Dalam praktik, jika kita membahas perencanaan pembangunan ekonomi daerah maka pengertian yang ketiga tersebut yang di atas yang lebih banyak digunakan, karena:

1. Dalam melaksanakan kebijaksanaan dan rencana pembangunan daerah diperlukan tindakan-tindakan dari brbagai lembaga pemerintah. Oleh karena itu, akan lebih praktis jika suatu negara dipecah menjadi beberapa daerah ekonomi berdasarkan satuan administratif yang ada.

2. Daerah yang batasnya ditentukan secara administratif lebih mudah dianalisis, karena biasanya pengumpulan data di berbagai daerah dalam suatu negara, pembagiannya didasarkan pada satuan administratif.

\section{PENGERTIAN PEMBANGUNAN EKONOMI DAERAH}

Pembangunan ekonomi daerah adalah suatu proses di mana pemerintah daerah dan masyarakatnya mengelola sumberdaya-sumberdaya yang ada dan membentuk suatu pola kemitraan antara pemerintah daerah dengan sektor swasta untuk menciptakan suatu lapangan kerja baru dan merangsang perkembangan kegiatan ekonomi (pertumbuhan ekonomi) dalam wilayah tersebut.

Masalah pokok dalam pembangunan daerah adalah terletak pada penekanan terhadap kebijakan-kebijakan pembangunan yang didasarkan pada kekhasan daerah yang bersangkutan (endogenous development) dengan menggunakan potensi sumberdaya manusia, kelembagaan, dan sumberdaya fisik secara lokal (daerah). Orientasi ini mengarahkan kita kepada pengambilan inisiatif-inisiatif yang berasal dari daerah tersebut dalam proses pembangunan untuk menciptakan kesempatan kerja baru dan merangsang peningkatan kegiatan ekonomi.

Pembangunan ekonomi daerah adalah suatu proses. Yaitu proses yang mencakup pembentukan institusi-institusi baru, pembangunan industri-industri alternatif, perbaikan kaasitas tenaga kerja yang ada untuk menghasilkan produk dan jasa yang lebih baik, identifikasi pasar-pasar baru, alih ilmu pengetahuan, dan pengembangan perusahaan-perusahaan baru.

Setiap upaya pembangunan ekonomi daerah mempunyai tujuan utama untuk meningkatkan jumlah dan jenis peluang kerja untuk masyarakat daerah. Dalam upaya untu mencapai tujuan tesebut. Pemerintah daerah dan masyarakatnya harus secara berama-sama mengambil inisiatif pembangunan daerah. 


\section{TEORI PERTUMBUHAN DAN PEMBANGUNAN DAERAH}

Saat ini tidak suatu teori pun yang mampu untuk menjelaskan pembangunan ekonomi daerah secara komprehensif.namun demikian, ada beberapa teori yang secara parsial yang dapat membantu kita untuk memahami arti penting pembangunan ekonomi daerah. Pada hakikatnya, inti dari teori-teori tersebut berkisar pada dua hal, yaitu pembahasan yang berkisar tentang metode dalam menganalisis perekonomian suatu daerah dan teori-teori yang membahas tentang faktor-faktor yang menentukan pertumbuhan ekonomi suatu daerah tertentu.

Pengembangan metode yang menganalisis perekonomian suatu daerah penting sekali kegunaannya untuk mengumplkan data tentang perekonomian daerah yang bersangkutan serta proses pertumbuhannya, yang kemudian dapat dipakai sebagai pedoman untuk menentukan tindakan-tindakan apa yang harus diambil untuk mempercepat laju pertumbuhan yang ada. Namun dipihak lain harus diakui, menganalisis perekonomian suatu daerah sangat sulit karena:

1. Data tentang daerah sangat terbatas terutama kalau daerah dibedakan berdaarkan pengertian daerah nodal. Dengan data yang sangat terbatas sangat sukar untuk menggunakan metode yang telah dikembangkan dalam memberikan gambaran mengenai perekonomian suatu daerah.

2. Data yang tersedia umumnya tidak sesuai dengan data yang dibutuhkan untuk analisis daerah, karena data yang terkumpul biasanya ditujukan untuk memenuhi kebutuhan analisis perekonomian secara nasional.

3. Data tentang perekonomian daerah sangat sukar dikumpulkan, sebab perekonomian daerah lebih terbuka dibandingkan dengan perekonomian nasional. Hal tersebut menyebabkan data tentang aliran-aliran yang masuk dan keluar dari suatu daerah sukar diperoleh.

4. Bagi NSB, di samping kekurangan data sebagai kenyataan yang umum, data yang ada yang terbatas itu pun banyak yang sulit untuk dipercaya, sehingga menimbulkan kesulitan untuk melakukan analisis yang memadai tentang keadaan perekonomian suatu daerah.

Kalau analisis pembangunan nasional dibandingkan dengan analisis pembangunan aerah, maka akan tampak bahwa analisis pembangunan ekonomi daerah sangat ketinggalan, baik ditinjau dari cakupan analisis maupun kedalamannya. Disamping itu, analisis regional yang ada bertitik-tolak dari analisis permasalahan dan kebijaksanaan pembangunan daerah di negara maju, padahal struktur perekonomian negara-negara maju sangat berbeda dengan struktur perekonomian NSB, demikian juga dengan struktur perekonomian daerahnya. Perbedaan struktur ini mengakibatkan perlunya analisis dan cara pendekata yang berbeda pila. berikut:

Jika kita buat suatu ringkasan, teori-teori tersebut dapat disajikan sebagai

Pembangunan daerah $=\mathrm{f}$ (sumberdaya alam, tenaga kerja, investasi, entrepreneurship, transportasi, komunikasi, komposisi industri,luas daerah,pasar ekspor,situasi ekonomi internasional,kapasitas pemerintah daerah,pengeluaran pemerintah pusat,dan bantuan-bantuan pembangunan).

\section{Teori Ekonomi Neo Klasik}

Peranan teori ekonomi Neo Klasik tidak terlalu besar dalam menganalisis pembangunan daerah (regional) karena teori ini tidak memiliki dimensi spasial yang signifikan. Namun demikian, teori ini memberikan 2 konsep pokok dalam 
pembangunan ekonomi daerah yaitu keseimbangan (equilibrium) dan mobilitas faktor produksi. Artinya, sistem perekonoman akan mencapai keseimbangan alamiahnya jika modal bisa mengalir tanpa restriksi (pembatasan). Oleh karena itu, modal akan mengalir dari daerah yang berupah tinggi menuju ke daerah yang berupah rendah.

\section{Teori Basis Ekonomi (Economic Base Theory)}

Teori basis ekonomi ini menyatakan bahwa faktor penentu utama pertumbuhan ekonomi suatu daerah adalah berhubungan langsung dengan permintaan akan barang dan jasa dari luar daerah. Pertumbuhan industri-industri yang menggunakan sumberdaya lokal, termasuk tenaga kerja dan bahan baku untuk diekspor, akan menghasilkan kekayaan daerah dan penciptaan peluang kerja (job creation).

Strategi pembangunan daerah yang muncul yang didasarkan pada teori adalah penekanan terhadap arti penting bantuan (aid) kepada dunia usaha yang mempunyai pasar secara nasional maupun internasional implementasi kebijakannya mencakup pengurangan hambatan/batasan terhadap perusahaanperusahaan yang berorientasi ekspor yang ada dan akan didirikan di daerah tersebut.

Kelemahan model ini adalah bahwa model ini didasarkan pada permintaan eksternal bukan internal. Pada akhirnya akan menyebabkan ketergantungan yang sangat tinggi terhadap kekuatan-kekuatan pasar secara nasional maupun global. Namun demikian, model ini sangat berguna untuk menentukan keseimbangan antara jenis-jenis industri dan sektor yang dibutuhkan masyarakat untuk mengembangkan stabilitas ekonomi.

\section{Teori Lokasi}

Para ekonomi regional sering mengatakan bahwa ada 3 faktor yang mempengaruhi pertumbuhan daerah yaitu: lokasi, lokasi, dan lokasi! Pernyataan tersebut sangat masuk akal jika dikaitkan dengan pengembangan kawasan industri. Perusahaan cenderung untuk meminimumkan biayanya dengan cara memilih lokasi yang memaksimumkan peluangnya untuk mendekati pasar. Model pengembangan industri kuno menyatakan bahwa lokasi yang terbaik adalah biaya yang termurah antara bahan baku dengan pasar.

Tentu saja banyak variabel lainnya yang mempengaruhi kualitas atau suitabilitas suatu lokasi misalnya upah tenaga kerja, biaya energi, ketersediaan pemasok, komunikasi, fasilitas-fasilitas pendidikan dan latihan (diklat).

keterbatasan dari teori lokasi ini pada saat sekarang adalah bahwa tegnologi dan komunikasi modern telah mengubah signifikansi suatu lokasi tertentu untuk kegiatan produksi dan distribusi barang.

\section{Teori Tempat Sentral}

Teori tempat sentral (central place theory) menganggap bahwa ada hirarki tempat (hierarchy of places). Setiap tempat sentral didukung oleh sejumlah tempat yang lebih kecil yang menyediakan sumberdaya (industri dan bahan baku). Tempat sentral tersebut merupakan suatu pemukiman yang menyediakan jasa-jasa bagi penduduk daerah yang mendukungnya.

Teori tempat sentral ini bisa diterapkan pada pembangunan ekonomi daerah, baik di daerah perkotaan maupun di pedesaan. Misalnya, perlunya melakukan pembedaan fungsi antara daerah-daerah yang bertetangga (berbatasan). Beberapa daerah bisa menjadi wilayah penyedia jasa sedangkan lainnya hanya sebagai daerah pemukiman.seorang ahli pembangunan ekonomi 
daerah dapat membantu masyarakat untuk mengembangkan peranan fungsional mereka dalam sistem ekonomi daerah.

\section{Teori Kausasi Kumulatif}

Kondisi daerah-daerah sekitar kota yang semakin buruk menunjukkan konsep dasar dari tesis kausasi kumulatif (cumulative causation) ini. Kekuatankekuatan pasar cenderung memperparah kesenjangan antara daerah-daerah tersebut (maju versus terbelakang). Daerah yang maju mengalami akumulasi keunggulan kompetitif dibanding daerah-daerah lainnya. Hal ini yang disebut Myrdal (1957) sebagai backwash effect.

\section{Model Daya Tarik (attraction)}

Teori daya tarik industri adalah model pembangunan ekonomi yang paling banyak digunakan oleh masyarakat. Teori ekonomi yang mendasarinya adalah bahwa suatu masyarakat dapat memperbaiki posisi pasarnya terhadap industrialis melalui pemberian subsidi dan intensif.

\section{PARADIGMA BARU TEORI PEMBANGUNAN EKONOMI DAERAH}

Teori pembangunan yang ada sekarang ini tidak mampu untuk menjelaskan kgiatan-kegiatan pembangunan ekonomi daerah secara tuntas dan komprehensif. Oleh karena itu, suatu pendekatan alternatif terhadap teori pembangunan dirumuskan di sini untuk kepentingan perencanaan pembangunan ekonomi daerah. Pendekatan ini merupakan sintesa dan perumusan kembali konsep-konsep yang telah ada. Pendekatan ini memberikan dasar bagi kerangka pikir dan rencana tindakan yang akan diambil dalam konteks pembangunan ekonomi daerah.

Pendekatan ini dapat disajikan pada tabel 1 berikut ini:

Tabel 1 Paradigma baru teori pembangunan ekonomi daerah

\begin{tabular}{|c|l|l|}
\hline KOMPONEN & \multicolumn{1}{|c|}{ KONSEP LAMA } & \multicolumn{1}{|c|}{ KONSEP BARU } \\
\hline Kesempatan kerja & $\begin{array}{l}\text { Semakin sanyak } \\
\text { perusahaan= semakin } \\
\text { banyak peluang kerja }\end{array}$ & $\begin{array}{l}\text { Perusahaan } \\
\text { mengembangkan } \\
\text { pekerjaan yang sesuai } \\
\text { dengan "kondisi" } \\
\text { penduduk daerah }\end{array}$ \\
\hline Basis pembangunan & $\begin{array}{l}\text { Pengembangan sektor } \\
\text { ekonomi }\end{array}$ & $\begin{array}{l}\text { Pengembangan lembaga- } \\
\text { lembaga ekonomi baru }\end{array}$ \\
\hline Aset-aset lokasi & $\begin{array}{l}\text { Keunggulan komparatif } \\
\text { didasarkan pada aset } \\
\text { fisik }\end{array}$ & $\begin{array}{l}\text { Keunggulan kompetitif } \\
\text { didasarkan pada kualitas } \\
\text { lingkungan }\end{array}$ \\
\hline Sumberdaya pengetahuan & $\begin{array}{l}\text { Ketersediaan angkatan } \\
\text { kerja }\end{array}$ & $\begin{array}{l}\text { Penegetahuan sebagai } \\
\text { pembangkit ekonomi }\end{array}$ \\
\hline
\end{tabular}

\section{PERAN PEMERINTAH DALAM PEMBANGUNAN DAERAH}

Ada 4 peran yang dapat diambil oleh pemerintah daerah dalam proses pembangunan ekonomi daerah yaitu sebagai entrepreneur, koordinator, fasilitator, dan stimulator bagi lahirnya inisiatif-inisiatif pembangunan daerah.

1. Entrepreneur

Dengan perannya sebagai entrepreneur, pemerintah daerah bertanggungjawab untuk menjalankan suatu usaha bisnis. Pemerintah daerah bisa mengembangkan suatu usaha sendiri (BUMD).Aset-aset 
pemerintah daerah harus dapat dikelolah dengan lebih baik sehingga secara ekonomis menguntungkan.

2. Koordinator

Pemerintah daerah dapat bertindak sebagai koordinator untuk menetapkan atau mengusulkan strategi-strategi bagi pembangunan di daerahnya. Perluasan dari peranan ini dalam pembangunan ekonomi bisa melibatkan kelompok-kelompok dalam masyarakat dalam proses pengumpulan dan pengevaluasian informasi ekonomi, misalnya tingkat kesempatan kerja, angkatan kerja, pengangguran dan sebagainya.

Dalam perannya sebagai koordinator, pemerintah daerah juga bisa melibatkan lembaga-lembaga pemerintah lainnya, dunia usaha, dan masyarakat dalam penyusunan sasaran-sasaran ekonomi, rencanarencana, dan strategi-strategi.

3. Fasilitator

Pemerintah daerah dapat mempercepat pembangunan melalui perbaikan lingkungan attitudinal (perilaku atau budaya mayarakat) di daerahnya. Hal ini akan mempercepat proses pembangunan dan prosedur perencanaan serta pengaturan penetapan daerah (zoning) yang lebih baik.

4. Stimulator

Pemerintah daerah dapat menstimulasi penciptaan dan pengembangan usaha melalui tindakan-tindakan khusus yang akan mempengaruhi perusahaan-perusahaan untuk masuk ke daerah tersebut dan menjaga agar perusahaan-perusahaan yang telah ada tetap berada di daerah tesebut. Stimulasi ini dapat dilakukan dengan cara antara lain: pembuatan brosurbrosur, pembangunan kawasan industri, pembuatan outlets untuk produkproduk industri kecil, membantu industri-industri kecil melakukan pameran.

\section{STRATEGI PERTUMBUHAN DAN PEMBANGUNAN EKONOMI STRATEGI UPAYA MINIMUM KRITIS}

Harvey leibenstein mengajukan tesis bahwa sebagian besar NSB dikecam oleh lingkaran setan kemiskinan (vicious circle of poverty) yang membuat mereka tetap berada pada tingkat keseimbangan pendapatan per kapita yang rendah. Jalan keluar dari kebuntuan ini adalah dengan melakukan suatu upaya minimum kritis (critical minimum effort) tertentu yang akan menaikkan pendapatan per kapita pada tingkat di mana pembangunan yang berkesinambungan (sustainable) akan terjadi. Leibanstein mengatakan bahwa dalam tahap transisi dari keadaan keterbelakangan ke keadaan yang lebih maju di mana kita dapat mengharapkan pertumbuhan jangka panjang yang mantap (steady economic growth) diperlukan suatu kondisi di mana suatu perekonomian harus mendapatkan rangsangan pertumbuhan yang lebih besar di atas batas minimum kritis tertentu.

Menurut Leibenstein, setiap ekonomi tunduk pada hambatan dan rangsangan. Hambatan berdampak menurunkan pendapatan per kapita dari tingkat sebelumnya, sementara rangsangan cenderung akan meningkatkan pendapatan itu mendapat rangsangan yang lebih kuat daripada factor-faktor yang dapat menurunkan pendapatan, maka usaha minimum kritis itu dapat tercapai dan suatu perekonomian akan bisa berkembang.

\section{STRATEGI PEMBANGUNAN SEIMBANG}

Istilah pembangunan seimbang itu diciptakan oleh Nurkse (1953). Strategi pembangunan seimbang bisa diartikan sebagai pembangunan berbagai 
jenis industri secara berbarengan (simultaneous) sehingga industri tersebut saling menciptakan pasar bagi yang lain. Selain itu, strategi pembangunan seimbang ini dapat juga diartikan sebagai keseimbangan pembangunan di berbagai sector. Misalnya antara sektor industri dan sektor pertanian, sektor luar negeri dan sektor domestik, dan antara sektor produktif dan sektor prasarana. Singkatanya, strategi pembangunan seimbang ini mengharuskan adanya pembangunan yang serentak dan harmonis di berbagai sector ekonomi sehingga semua sector tumbuh bersama.

Untuk itu, diperlukan keseimbangan antara sisi permintaan dan sisi penawaran. Sisi penawaran memberikan tekanan pada pembangunan serentak dari semua sektor yang saling berkaitan dan berfungsi meningkatkan penawaran barang. Ini meliputi pembangunan serentak dan harmonis dari barang setengah jadi, bahan baku, sumberdaya energi, pertanian, pengairan, transportasi dan lainlain serta semua industri yang memproduksi barang konsumen.

Sebaliknya, sisi permintaan berhubungan dengan penyediaan kesempatan kerja yang lebih besar dan penambahan pendapatan agar permintaan barang dan jasa dapat tumbuh. Sisi ini berkaitan dengan industri yang sifatnya saling melengkapi, industri barang konsumaen, khususnya produk pertanian dan industri manufaktur. Jika semua industri dibangun secara serentak maka jumlah tenaga kerja yang terserap akan sangat besar. Dengan cara ini akan tercipta permintaan barang-barang dari masing-masing industri satu sama lain, dan semua barang akan habis terjual.

Pembangunan seimbang ini biasanya dilaksanakan dengan maksud untuk menjaga agar proses pembangunan tidak menghadapi hambatan-hambatan dalam:

(a) memperoleh bahan baku, tenaga ahli, sumberdaya energi (air dan listrik), dan fasilitas-fasilitas untuk mengangkut hasil-hasil produksi ke pasar.

(b) Memperoleh pasar untuk barang-barang yang telah dan yang akan diproduksikan.

Dengan demikian pembangunan seimbang itu dapatlah didefinisikan sebagai usaha pembangunan yang berupaya untuk mengatur program investasi sedemikian rupa sehingga sepanjang proses pembangunan tidak akan timbul hambatan-hambatan yang bersumber dari penawaran maupun permintaan.

Sementara itu, pembangunan tak seimbang merupakan keadaan yang berlawanan dengan keadaan pada pembangunan seimbang. Istilah ini digunakan untuk menyatakan bahwa program pembangunan disusun sedemikian rupa sehingga dalam perekonomian tersebut akan timbul kelebihan dan kekurangan dalam berbagai sektor sehingga menimbulkan distorsi-distorsi dan ketidakstabilan dalam perekonomian.

Jika kita akan melaksanakan pembangunan seimbang, maka tingkat investasi yang harus dilakukan besarnya jauh melebihi tingkat investasi yang dilakukan pada sebelum usaha pembangunan dilakukan. Oleh karena itu, strategi pembangunan seimbang ini oleh sebagian ekonomi disebut pula teori dorongan besar-besaran (big push theory).

\section{STRATEGI PEMBANGUNAN TAK SEIMBANG}

Strategi pembangunan tak seimbang ini dikemukakan oleh Albert O. Hirschman dan Paul Streeten. Menurut mereka, pembangunan tak seimbang adalah pola pembangunan yang lebih cocok untuk mempercepat proses pembangunan di NSB. Pola pembangunan tak seimbang ini, menurut Hirschman, berdasarkan pertimbangan sebagai berikut: 
(1) Secara historis pembangunan ekonomi yang terjadi coraknya tidak seimbang.

(2) Untuk mempertinggi efisiensi penggunaan sumberdaya-sumberdaya yang tersedia, dan

(3) Pembangunan tak seimbang akan menimbulkan kemacetan (bottlenecks) atau gangguan-gangguan dalam proses pembangunan tetapi akan menjadi pendorong bagi pembangunan selanjutnya.

Menurut Hirschman, jika kita mengamati proses pembangunan yang terjadi antara dua periode waktu tertentu akan tampak bahwa berbagai sektor kegiatan ekonomi mengalami perkembangan dengan laju yang berbeda, yang berarti pula bahwa pembangunan berjalan dengan baik tidak seimbang. Perkembangan sektor pemimpin (leading sector) akan merangsang perkembangan sektor lainnya. Begitu pula perkembangan di suatu industri tertentu akan merangsang perkembangan industri-industri lain yang erat keterkaitannya dengan industri yang mengalami perkembangan tersebut.

Pembangunan tak seimbang ini juga dianggap lebih sesuai untuk dilaksanakan di NSB karena negara-negara tersebut menghadapi masalah kekurangan sumberdaya. Dengan melaksanakan program pembangunan tak seimbang maka uasaha pembangunan pada suatu periode waktu tertentu di pusatkan pada beberapa sektor yang akan mendorong penanaman modal yang terpengaruh (induced investment) di berbagai sektor pada periode waktu berikutnya. Oleh karena itu, sumberdaya-sumberdaya yang sangat langka itu dapat digunakan secara lebih efisien pada setiap tahap pembangunan.

Seperti diungkapkan di muka, pembangunan tak seimbang ini akan menciptakan gangguan-gangguan dan ketidakseimbangan-ketidakseimbangan dalam kegiatan ekonomi. Keadaan tersebut akan menjadi perangsang untuk melaksanakan investasi yang lebih banyak pada masa yang akan datang. Dengan demikian pembangunan tak seimbang akan mempercepat pembangunan ekonomi pada masa yang akan datang.

\section{STRATEGI PEMBANGUNAN EKONOMI DAERAH}

Secara umum tujuan strategi pembangunan ekonomi adalah sebagai berikut: pertama, mengembangkan lapangan kerja bagi penduduk yang ada sekarang. Tujuan perencanaan pembangunan ekonomi dan pengerjaan adalah lebih untuk memberikan kesempatan kerja untuk penduduk yang ada sekarang ketimbang menarik para pekerja baru. Kedua, mencapai stabilitas ekonomi daerah. Pembangunan ekonomi akan sukses jika mampu memenuhi kebutuhan dunia uasaha (misalnya: lahan, sumber keuangan, infrastruktur, dan sebagainya yang beragam. Hal ini untuk mengantisipasi kemungkinan-kemungkinan fluktuasi ekonomi sektoral, yang pada akhirnya akan mempengaruhi kesempatan kerja masyarakat.

Strategi pembangunan ekonomi daerah dapat dikelompokkan menjadi 4 kelompok besar yaitu:(1) strategi pembangunan fisik/lokalitas (Locality or Physical Development Strategy), (2) strategi pengembangan dunia usaha (Business Development Strategy), (3) Srategi Pengembangan Sumberdaya Manusia (Human Resource Development Strategy), dan (4) Strategi Pengembangan Masyarakat (Community-based Development Strategy).

\section{Strategi Pengembangan Fisik/Lokalitas}

Melalui pengembangan program perbaikan kondisi fisik/lokalitas daerah yang ditujukan untuk kepentingan pembangunan industri pembangunan industri dan perdagangan, pemerintah daerah akan berpengaruh positif bagi 
pembangunan dunia usaha daerah. Secara khusus, tujuan strategi pembangunan fisik/lokalitas ini adalah untuk menciptakan identitas daerah/ kota, memperbaiki basis pesona (amenity base) atau kualitas hidup masyarakat, dan memperbaiki daya tarik pusat kota (civic center) dalam upaya untuk memperbaiki dunia usaha daerah.

Alat untuk mencapai tujuan pembangunan fisik/lokalitas daerah ini mencakup antara lain:

- Pembuatan bank tanah (landbanking). Hal ini bertujuan agar kita mempunyai data tentang tanah yang penggunaannya kurang optimal, belum dikembangkan, atau salah penggunaan, dan sebagainya. Pembuatan katalog mengenai luas dan lokasi tanah yang terus diperbaharui akan sangat bermanfat untuk proses pengambilan kebijakan daerah.

- Pengendalian perencanaan dan pembangunan. Jika hal ini dilakukan dengan benar akan memperbaiki iklim investasi di daerah dan memperbaiki citra pemerintah daerah.

- Penataan kota (townscaping). Kemajuan di pusat-pusat perdagangan dapat dicapai melalui perbaikan-perbaikan sarana jalan raya (misalnya penanaman pohon-pohon yang rindang dan indah) dan perbaikan-perbaikan sarana pusat pertokoan (misalnya perbaikan tampilan maka pertokoan atau penetapan standar fisik bagi suatu bangunan pertokoan).

- Pengaturan tata ruang (zoning) dengan baik akan merangsang pertumbuhan dan pembangunan ekonomi daerah. Peruntukan lahan harus jelas dan tepat, misalnya penetapan kawasan pemukiman, kawasan industri, kawasan perdagangan, dan kawasan hijau.

- Penyediaan perumahan dan pemukiman yang baik akan berpengaruh positif bagi dunia usaha. Selain itu, kegiatan di sektor ini juga akan menciptakan kesempatan kerja.

- Penyediaan infrastruktur seperti: sarana air bersih, listrik, tamantaman, sarana parkir, dan sebagainya menjadi daya tarikutama juga bagi calon investor dan dunia usaha.

- Dan sebagainya.

\section{Strategi Pengembangan Dunia Usaha}

Pengembangan dunia usaha merupakan komponen penting dalam perencanaan pembangunan ekonomi daerah karena daya tarik, kreasi, atau daya tahan kegiatan dunia usaha merupakan cara terbaik untuk menciptakan perekonomian daerah yang sehat.

Beberapa alat untuk mengembangkan dunia usaha ini yakni:

- Penciptaan iklim usaha yang baik bagi dunia usaha, melalui pengaturan dan kebijakan yang memberikan kemudahan bagi dunia usaha dan pada saat yang sama mencegah penurunan kualitas lingkungan.

- Pembuatan pusat informasi terpadu yang dapat memudahkan masyarakat dunia usaha untuk berhubungan dengan aparat pemerintah daerah untuk segala macam kepentingan, terutama mengetahui masalah perijinan, rencana pembangunan ekonomi daerah, pemerintah daerah, ketersedian lahan, ijin mendirikan bangunan, dan sebagainya 
- Pendirian pusat konsultasi dan pengembangan usaha kecil. Selain peranannya yang penting sebagai penyerap tenaga kerja dan sebagai sumber dorongan kewirausahaan, usaha kecil sering kali mengalami kegagalan atau tidak dapat berkembang dengan baik. Faktor penyebab utamanya adalah jeleknya manajemen usaha kecil. Oleh karena itu, perlu didirikannya suatu pusat konsultasi dan pengembangan usaha kecil yang siap untuk membantu para pengusaha kecil tersebut sehingga kinerjanya meningkat.

- Pembuatan sistem pemasaran bersama untuk menghindari skala yang tidak ekonomis dalam produksi, meningkatkan daya saing terhadap produk-produk impor, dan meningkatkan sikap kooperatif antar sesama pelaku bisnis.

- Pembuatan lembaga penelitian dan pengembangan (Litbang). Peningkatan persaingan di dunia yang berbasiskan ilmu pengetahuan sekarang ini menuntut pelaku bisnis dan pemerintah daerah untuk secara terus menerus melakukan kajian tentang pengembangan produk baru, pengembangan teknologi baru, dan pencarian pasarpasar baru.

- Dan sebagainya.

\section{Strategi Pengembangan Sumberdaya Manusia}

Sumberdaya manusia merupakan aspek yang paling penting dalam proses pembangunan ekonomi. Oleh karena peningkatan kualitas dan ketrampilan sumberdaya manusia adalah suatu keniscayaan.

Pengembangan kualitas sumberdaya manusia ini dapat dilakukan dengan cara antara lain:

- Pelatihan dengan sistem customized training. Sistem pelatihan seperti ini adalah sistem pelatihan yang dirancang secara khusus untuk memenuhi kebutuhan dan harapan si pemberi kerja.

- Pembuatan bank keahlian (skillbanks). Informasi yang ada pada bank keahlian berisi data tentang keahlian dan latar belakang orang yang menganggur di suatu daerah. Informasi ini bermanfaat bagi pengembangan jenis pekerjaan yang sesuai dengn kemampuan dan ketrampilan para penganggur tersebut. Selain itu, informasi ini juga merupakan informasi cadangan keahlian yang pada akhirnya dapat juga diunakan untuk mengisi lowongan-lowongan kerja yang muncul di daerah tersebut. Pada akhirnya, bank keahlian ini dapat juga digunakan untuk pembentukan koperasi.

- Penciptaan iklim yang mendukung bagi berkembangnya lembagalembaga pendidikan dan ketrampilan (LPK) di daerah. Berkembangnya lembaga-lembaga pendidikan dan ketrampilan di suatu daerah secara tidak langsung bermanfaat bagi peningkatan kualitas sumberdaya manusia di daerah tersebut. Misalnya: lembaga kursus bahasa, lembaga kursus komputer, lembaga kursus perbengkelan, dan lembaga kursus perhotelan, dan sebagainya.

- pengembangan lembaga pelatihan bagi penyandang cacat. Hal ini penting bagi si penyandang cacat itu sendiri untuk meningkatkan rasa harga diri dan percaya dirinya. Selainitu, untuk jenis-jenis pekerjaan tertentu kadang-kadang penyandang cacat mempunyai beberapa kelebihan.

- Dan sebagainya. 


\section{Strategi Pengembangan Ekonomi Masyarakat}

Kegiatan pengembangan masyarakat ini merupakan kegiatan yang ditujukan untuk mengembangkan suatu kelompok masyarakat tertentu di suatu daerah. Dalam bahasa populer sekarang ini sering juga dikenal dengan istilah kegiatan pemberdayaan (empowerment) masyarakat. Kegiatan-kegiatan seperti ini berkembang marak di indonesia belakangan ini karena ternyata kebijakan umum ekonomi yang ada tidak mampu memberikan manfaat bagi kelompokkelompok masyarakat tertentu. Tujuan kegiatan ini adalah untuk menciptakan manfaat sosial, misalnya melalui penciptaan proyek-proyek padat karya untuk memenuhi keuntungan dari usahanya.

\section{PENUTUP}

Strategi pertumbuhan dan pembangunan ekonomi daerah adalah sangat mutlak diperlukan serta diterapkan dalam rangka mempercepat pertumbuhan dan pembangunan ekonomi daerah yang bersangkutan. Untuk itu peran pemerintah sangat penting untuk mendorong bahkan meningkatkan kapasitas pembangunan ekonomi suatu daerah dengan berdasarkan pada kondisi serta potensi yang dimiliki oleh masing-masing daerah.

\section{DAFTAR PUSTAKA}

Bintoro Tjokroamidjojo, 1994 : Perencanaan Pembangunan, Haji Masagung, Jakarta.

\section{3 : Kebijaksanaan dan Administrasi} Pembangunan, Perkembangan Teori dan Praktek, LP3ES.

Lincolin Arsyad, 1999 : Pengantar Perencanaan dan Pembangunan Ekonomi Daerah, BPFE Yogyakarta.

Ginanjar Adisasmita, 1997 : Administrasi Pembangunan, Perkembangan Pemikiran dan Prakteknya di Indonesia, LP3ES.

Deddy Supriady Bratakusuma, 2000 : Pembangunan Daerah dan Perspektif UU No. 22 Tahun 1999, dalam Prosiding Lokakarya Perencanaan Pembangunan dan Implementasi Otonomi Daerah (Walikota/Bupati seSulawesi). Editor A. Madjid Sallatu dan Agussalim.

Kunarjo, 1993 : Perencanaan dan Pembiayaan Pembangunan, Jakarta, Lembaga Penerbit FE-UI. 